\title{
Nitric Oxide Synthase in Müller Cells and Neurons of Salamander and Fish Retina
}

\author{
B. A. Liepe, ${ }^{1}$ C. Stone, ${ }^{1}$ J. Koistinaho, ${ }^{2}$ and D. R. Copenhagen' \\ 'Departments of Ophthalmology and Physiology, University of California, San Francisco, California 94143 and \\ ${ }^{2}$ Department of Biochemistry \& Biotechnology, University of Kuopio, FIN-70211 Kuopio, Finland
}

\begin{abstract}
Nitric oxide synthase (NOS) is the biosynthetic enzyme of the signaling molecule nitric oxide (NO). NO donors have been reported to modulate conductances in cell types throughout the retina, from photoreceptors to ganglion cells. Previously, NOS immunoreactivity has been reported in amacrine cells and cells within the ganglion cell layer. Here, we have examined the cellular localization of NOS in the retinas of salamander, goldfish, and catfish using both an affinitypurified antiserum to brain NOS and NADPH diaphorase (NADPHd) histochemistry. These markers indicate that an NOS-like enzyme is localized not only to presumptive amacrine cells but also, depending on the species, to photoreceptor ellipsoids, to somata within the ganglion cell layer, and to horizontal cells. In addition to these neurons, our results indicate that Müller cells, the radial glia of the retina, also contain an NOS-like enzyme. In support of this latter conclusion, cells morphologically similar to Müller cells were positive for NADPHd staining in all three species. In salamander, NOS-like immunoreactivity, NADPHd staining, and binding of anti-GFAP (a marker for glia) were localized to cells that were morphologically indistinguishable from Müller cells. In goldfish, reactivity to both anti-NOS and anti-vimentin (a marker for glia) colocalized to radial processes extending through the inner retina to the inner limiting membrane. These observations are the first to indicate the presence of an NOS-like enzyme in Müller cells and suggest that these glia could be a ready source of NO for target neurons throughout the retina.
\end{abstract}

[Key words: nitric oxide synthase (NOS), nitric oxide (NO), retina, Müller cell, NADPH diaphorase]

Nitric oxide (NO) has been shown to modulate a number of cellular functions in both neuronal and non-neuronal cells (for review, see Moncada, 1992; Nathan, 1992; Snyder, 1992). This

\footnotetext{
Received Mar. 15, 1994; revised June 3, 1994; accepted June 8, 1994.

We thank Dr. David S. Bredt for generously donating the NOS antiserum. We are indebted to Dr. Matthew LaVail, Dr. Michael Mathes, and Mr. Douglas Yasumura for their help and guidance throughout this study. To Dr. Stephen Sagar we owe a special thanks for helpful suggestions and the use of laboratory space in the initial stages of this study. We thank Walter Denn and Dr. Frank H. Eeckman for help with the figures and table. Last, we thank Dr. Alexander Ball for his helpful comments. This work was supported by EY01869 (D.R.C. and J.K.) T32NS07067-15 and F32-EY06477 (B.A.L.), and EY07120-01 and F32-EY06435 (C.S.).

Correspondence should be addressed to B. A. Liepe, Departments of Ophthalmology and Physiology, Box 0730, University of California, San Francisco, San Francisco, CA 94143.

Copyright (C) 1994 Society for Neuroscience $0270-6474 / 94 / 147641-14 \$ 05.00 / 0$
}

molecule is synthesized from $l$-arginine by nitric oxide synthase (NOS; Deguchi and Yoshioka, 1982; Palmer et al., 1988), and has been shown to activate soluble guanylyl cyclase (Arnold et al., 1977) and increase ADP-ribosylation of specific protein substrates (Brüne and Lapetina, 1989; Zhang et al., 1994) in appropriate target cells. Bccausc NO is a short-lived gascous molecule, it is generally assumed that the synthetic enzyme NOS must be located either in the target cells or in cells that are immediately adjacent to the target cells (for review, see Garthwaite, 1991). Knowledge of the cell types containing NOS is an important factor in determining whether $\mathrm{NO}$ acts as a neuromodulator in vivo. The cellular localization of NOS has relied heavily on both antisera directed against specific isoforms of NOS and on nicotinamide adenine dinucleotide phosphate diaphorase (NADPHd) histochemistry. NADPHd activity is a functional part of the NOS enzyme and is required for NO production (Marletta et al., 1988; Palmer and Moncada, 1989; Bredt et al., 1991). In neurons (Dawson et al., 1991; Hope et al., 1991), macrophages (Mitchell et al., 1992), endothelia (Tracey et al., 1993), and glia (Galea et al., 1992), NOS and NADPHd staining has been colocalized or simultaneously induced. Thus, in a variety of cell types, NADPHd staining has proven to be a marker for NOS-positive cells.

It has been suggested that NO modulates certain cellular functions in the retinas of lower vertebrates. NO donors or inhibitors of NOS have been shown to modify light-induced membrane hyperpolarization in photoreceptors (K.-F. Schmidt et al., 1992), electrical coupling in horizontal cells (DeVries and Schwartz, 1989; Miyachi et al., 1990), and activate cGMP-gated conductances in On-bipolar cells (Shiells and Falk, 1992). Recently, NO donors have also been shown to modulate cGMP-gated conductances in ganglion cells isolated from the rat retina (Ahmad et al., 1994). Despite the observations that NO donors and NOS inhibitors have been shown to modulate conductances in different retinal cell types, little information is available concerning the cellular localization of NOS in the retinas of lower vertebrate species. The majority of studies to date have focused on the cellular localization of NOS in the mammalian retina. In the rat retina, both NOS immunoreactivity to the neuronal isoform and NADPHd staining have been localized to a small subset of amacrine cells and cells within the ganglion cell layer (Dawson et al., 1991; Yamamoto et al., 1993). An NOS-like enzymatic activity has also been reported in isolated bovine rod photoreceptors (Venturini et al., 1991). Here, we have examined the cellular localization of brain NOS in the retinas of the salamander, goldfish, and catfish. The results presented here indicate that NOS is localized, not only to certain classes of retinal neuron, but also to Müller cells, the radial glia of the retina. 


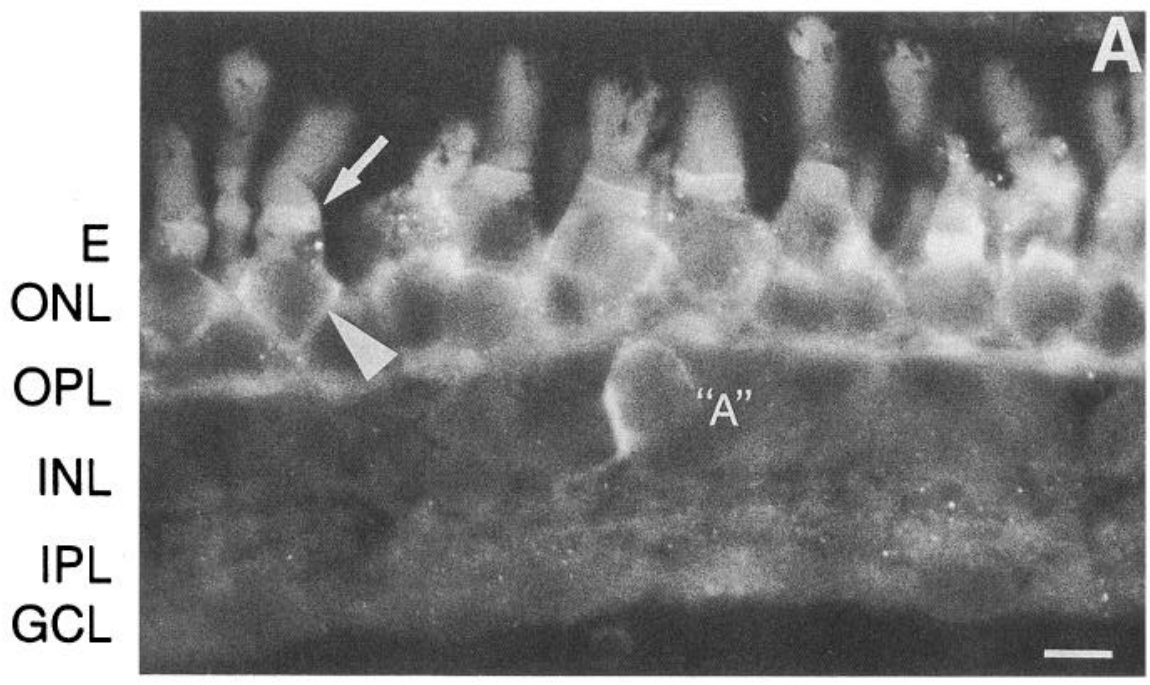

Figure 1. NOS-like immunoreactivity in the salamander retina. $A$, Binding of NOS antiserum visualized with FITC. Fluorescent label is observed in presumptive amacrine cell (" $A$ ") in the INL, along with the OPL, areas around nuclei in ONL (arrowhead), and in ellipsoids $(E ;$ arrow). This image was taken from the peripheral retina where the INL is relatively thin. This creates the impression that the cell labeled " $A$ " is positioned rather distally within the INL. $B$, Binding of NOS antiserum visualized with $\mathrm{DAB}$ /peroxidase system. Note dark staining of cells in INL (" $A$ ") and of a cell in GCL (arrowhead); staining is also apparent in IPL, OPL, rod and cone ellipsoids (arrows), and areas around photoreceptor nuclei. The slight dehydration of the tissue has altered the morphology of the ellipsoids. $C$, This slightly tangential section illustrates the lack of staining in the absence of the NOS antiserum visualized with $\mathrm{DAB}$ / peroxidase system. Abbreviations: $E$, photoreceptor ellipsoids; $O N L$, outer nuclear layer; $O P L$, outer plexiform layer; $I N L$, inner nuclear layer; $I P L$, inner plexiform layer; $G C L$, ganglion cell layer. Scale bars, $10 \mu \mathrm{m}$.
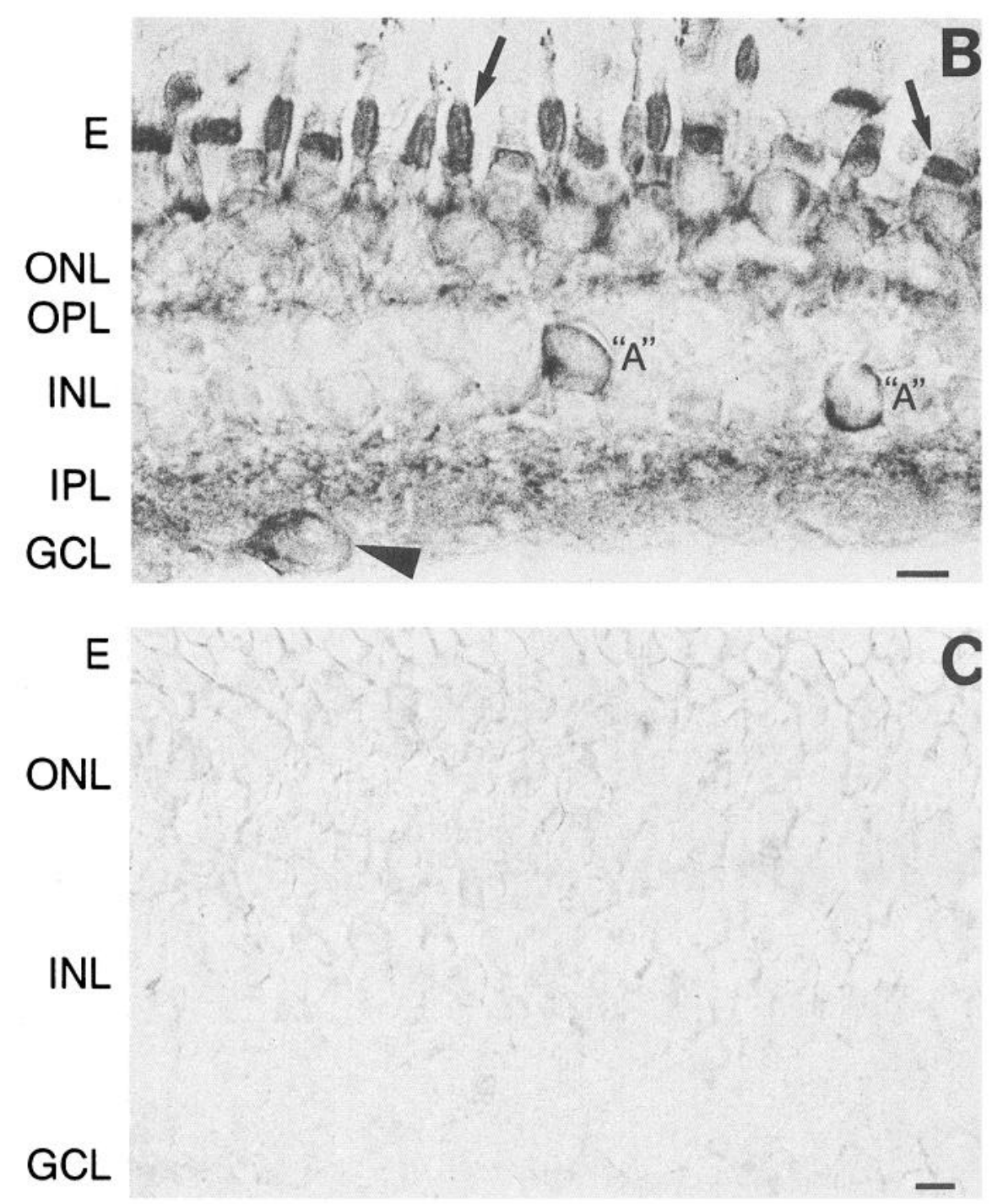

\section{Materials and Methods}

Animals. For these studies larval salamander (Ambystoma tigrinum), adult goldfish (Carassius auratus), both adult ( $>11$ inches) and juvenile ( $<7$ inches) catfish (Ictalurus punctatus), and an adult black-hooded, black-eyed RCS-rdy ${ }^{+} \mathrm{p}^{+}$rat were used. All species were obtained from commercial vendors and handled and killed according to the NIH guidelines for the use of laboratory animals.

Immunocytochemistry. Eyecups were isolated from light-adapted fish and from dark-adapted salamanders that had been maintained in dark- 


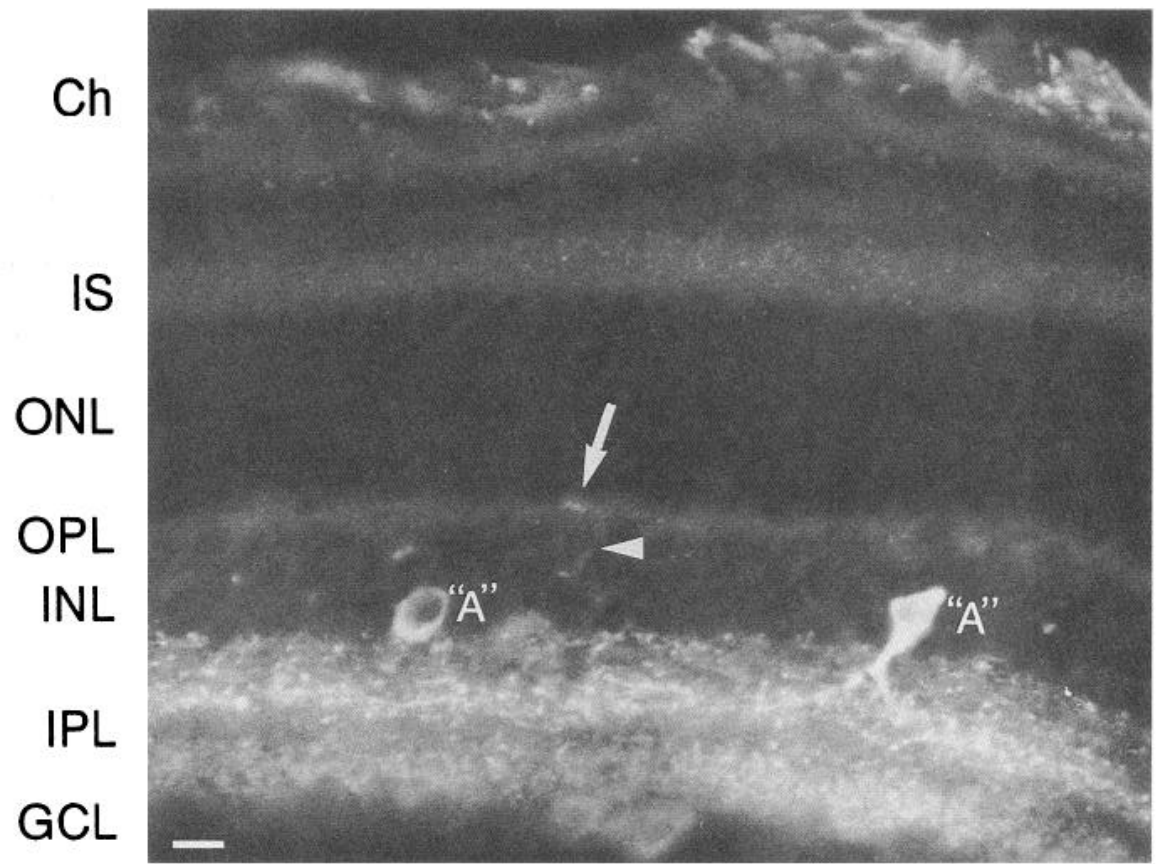

Figure 2. NOS-like immunoreactivity in the rat retina. Note pronounced labeling of presumptive amacrine cells (" $A$ ") at the inner margin of the INL and the punctate and stratified labeling in IPL. Labeling is also apparent in the choroid $(\mathrm{Ch})$, in an occasional area in OPL (arrow) and around nuclei located at the distal margin of the INL (arrowhead). In some sections, faint labeling at the IS and of radially oriented structures in the ONL was observed. $I S$, inner segments. Other abbreviations are as in Figure 1. Scale bar, $10 \mu \mathrm{m}$. ness for $90 \mathrm{~min}$. Immediately after isolation, eyecups were submerged

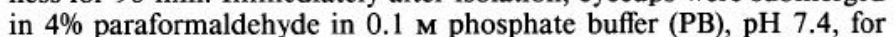
$2.5-3 \mathrm{hr}$ at $4^{\circ} \mathrm{C}$. After washing in $0.1 \mathrm{M} \mathrm{PB}$, the eyecups were immersed in 20\% sucrose/PB for 3-16 hr, and then oriented and frozen in OCT embedding medium (Tissue Tek, Miles, Inc., Elkhart, IN). Frozen sections $(10-20 \mu \mathrm{m})$ were cut on a cryostat, mounted onto gelatin-coated slides, and air dried. Sections were washed $30 \mathrm{~min}$ in PB and then preincubated in $\mathrm{PB}$ containing $0.1 \%$ bovine serum albumin, $0.2 \%$ Triton $\mathrm{X}-100$, and $2 \%$ normal goat serum (PB-G) at room temperature. Sections were then incubated overnight at room temperature in PB-G containing one of the following: a previously characterized affinity-purified rabbit antiserum directed against brain NOS (donated by D. S. Bredt; Bredt et al., 1990) diluted 1:30, a mouse monoclonal anti-GFAP (glial fibrillary acidic protein; Sigma, St. Louis, MO, clone G-3893) diluted 1:50, or a mouse monoclonal anti-vimentin (Sigma, St. Louis, MO, clone V-6630) diluted 1:40. For double labeling with the NOS and vimentin antisera, the sections were preincubated with $\mathrm{PB}$ containing $0.1 \%$ bovine serum albumin, $0.2 \%$ Triton $\mathrm{X}-100,1 \%$ normal goat serum and $1 \%$ normal horse serum. NOS antibody binding was visualized with either FITC-conjugated anti-rabbit IgG (1:40; Boehringer-Mannheim, Indianapolis, IN) or an avidin-biotin-peroxidase system (Vector Laboratories, Burlingame, CA) using diaminobenzidine (DAB; Sigma, St. Louis, MO) as a chromogen. Anti-vimentin and anti-GFAP binding was visualized with rhodamine-conjugated anti-mouse IgG (1:40; Boehringer-Mannheim, Indianapolis, IN) or lissamine rhodamine B sulfonyl chloride (LRSC)-conjugated anti-mouse IgG (1:70; Jackson ImmunoResearch Laboratories, Inc., West Grove, PA). For control sections, the primary antibodies were omitted in both single- and doublelabel experiments. Sections were mounted in buffered glycerol and examined with a microscope equipped for epifluorescence and bright-field illumination. Similar exposure times were used when photographing experimental and control sections under epifluorescence.

NADPH diaphorase histochemistry. NADPH diaphorase (NADPHd) histochemistry was performed on both retinal sections and on isolated whole retinas. For the histochemistry reaction, frozen retinal sections were prepared in the same manner as described above for immunocytochemistry. The sections were rinsed in $0.1 \mathrm{~m}$ Tris buffer, $\mathrm{pH} 8.0$, for $30 \mathrm{~min}$ and then incubated for $15-75 \mathrm{~min}$ in a reaction mixture (modified from Scherer-Singler et al., 1983; Sagar, 1990) containing 0.2 mm nitro blue tetrazolium (NBT), $1 \mathrm{~mm}$ NADPH dissolved in $0.2 \mathrm{~mm}$ sodium carbonate/bicarbonate buffer, and $0.2 \%$ Triton X-100 in $0.1 \mathrm{M}$ Tris buffer, $\mathrm{pH} 8.0$, at $37^{\circ} \mathrm{C}$. After incubation at $37^{\circ} \mathrm{C}$, the sections were rinsed in ice-cold $\mathrm{PB}$ and coverslipped in buffered glycerol. All chemicals for this reaction mixture were purchased from Sigma (St. Louis, MO).
For control experiments, NADPH was omitted from the reaction mixture.

In an alternative method, NADPHd reactions were performed on isolated retinas before embedding and sectioning. Here, retinas from all three species were isolated from dark-adapted animals. Dark adaptation facilitated the separation of the retina from the retinal pigment epithelium. Catfish were dark adapted overnight and goldfish and salamanders for $90 \mathrm{~min}$. Retinas from fish were isolated under dim red illumination and those from salamander under room light. After fixation for $2.5 \mathrm{hr}$ in $4 \%$ paraformaldehyde in $0.1 \mathrm{M} \mathrm{PB}, \mathrm{pH} 7.4$, at $4^{\circ} \mathrm{C}$, retinas were rinsed in $0.1 \mathrm{M}$ Tris buffer and reacted for NADPHd activity as described above with the exception that they were incubated in the reaction mixture for $1-3 \mathrm{hr}$. Retinas were then rinsed in ice-cold PB and infiltrated and embedded in JB-4 plastic resin (Polysciences, Inc., Warrington, PA). Retinas embedded in JB-4 were sectioned on a microtome at 5$35 \mu \mathrm{m}$ and examined under bright-field optics. Some retinas were examined as whole-mounts coverslipped in buffered glycerol or postfixed and sliced with a tissue chopper at $100-150 \mu \mathrm{m}$ and viewed under Nomarski optics. The number of animals used for each protocol is presented as $n$.

\section{Results}

\section{NOS localization in the salamander retina}

In the salamander retina, NOS-like immunoreactivity $(n=6)$ was observed in an occasional cell body and processes within the inner nuclear layer. These cell bodies were judged to be those of amacrine cells based on their round cell body shape and lateral processes extending toward the inner plexiform layer (Vallerga, 1981; Yang et al., 1991). Immunoreactivity was seen in somata of cells in the ganglion cell layer, and in the inner and outer plexiform layers. Immunoreactive cells in the ganglion cell layer could be either ganglion cells or displaced amacrine cells (Ball and Dickson, 1983). NOS-like immunoreactivity was also apparent in areas surrounding photoreceptor nuclei and in rod and cone photoreceptor ellipsoids. In Figure $1, A$ and $B$ show two examples of NOS-like immunoreactivity. In Figure $1 A$ FITC was used to visualize NOS antiserum binding, and in Figure $1 B \mathrm{DAB}$ /peroxidase system was used for visualization. The FITC marker emphasized NOS-like immunoreactivity in 
Table 1. Relative intensity of NOS-like immunoreactivity and NADPHd staining

\begin{tabular}{|c|c|c|c|c|c|c|}
\hline & \multicolumn{2}{|c|}{ Salamander } & \multicolumn{2}{|c|}{ Goldfish } & \multicolumn{2}{|l|}{ Catfish } \\
\hline & NOS-I & NADPHd & NOS-I & NADPHd & NOS-I & NADPHd \\
\hline Photoreceptor ellipsoids & ++ & +++ & $?$ & +++ & $?$ & +++ \\
\hline Müller glia & ++ & +++ & ++ & + & - & +++ \\
\hline Horizontal cells & - & + & + & +++ & - & $+?$ \\
\hline On-bipolar cells & - & - & + & + & - & - \\
\hline Amacrine cells & ++ & ++ & $+t$ & ++ & + & $+?$ \\
\hline Cells in GCL & + & - & + & + & - & + \\
\hline
\end{tabular}

Data show qualitative assessment of the degree of NOS-like immunoreactivity (NOS-I) and NADPHd staining (NADPHd) in the retinas of salamander, goldfish, and catfish. Relative degree of labeling: +++ , strong labeling;,++ moderate labeling; +, mild labeling; -, no labeling detected; +?, labeling suspected but not definitive; ?, labeling not detectable by our methods.

areas surrounding the photoreceptor nuclei, but did not readily reveal immunoreactivity in ellipsoids and in the inner plexiform layer. From these figures it is not apparent whether the immunorcactivity surrounding the photoreceptor nuclei could be in the photoreceptor cytoplasm or in processes from other retinal cells. The DAB/peroxidase marker tended to enhance staining in the inner plexiform layer and photoreceptor ellipsoids. Labeled somata of cells in both the inner nuclear and ganglion cell layers were clearly seen. The specificity of the NOS-like immunoreactivity in the ellipsoids was best determined when $\mathrm{DAB}$ was used as a chromagen, rather than FITC, due to autofluorescence of salamander ellipsoids. Figure $1 \mathrm{C}$ demonstrates that there was no specific staining in the absence of the NOS antiserum when the $\mathrm{DAB}$ /peroxidase marker was used for visualization.

To confirm that our procedures did not alter the binding of the antiserum we also examined NOS-like immunoreactivity in the rat retina $(n=1)$. Figure 2 shows robust staining of a few somata in the inner nuclear layer and processes in the inner plexiform layer. These results confirmed the previous findings of Yamamoto et al. (1993). As illustrated in Figure 2, we also found light staining in limited areas of the outer plexiform layer and in areas surrounding nuclei located at the distal margin of the inner nuclear layer (Fig. 2). Specific staining of the choroid was also observed.

\section{NADPH diaphorase localization in the salamander retina}

NADPHd staining was examined in two different retinal preparations. The intensity of staining in various cell types differed somewhat between the two preparations. In the "retinal section" preparation, fixed, frozen, retinal sections were air-dried and then reacted for NADPHd activity. In the "isolated retina" preparation, fixed, isolated retinas were first reacted for NADPHd activity, embedded in plastic, and then sectioned. In both preparations, the absence of $\mathrm{N} \Lambda \mathrm{DPH}$ (Figs. $3 C ; 7 C, D ; 8 C$ ) resulted in the complete lack of staining. Therefore, the reduction of NBT to the dark blue diformazan dye product is NADPH dependent and most probably indicative of NADPHd activity.

In the retinal section preparations, the pattern of NADPHd staining was similar to that obtained with the NOS antiserum. Dark staining was observed in a subset of presumptive amacrine cells, throughout both plexiform layers, in photoreceptor ellipsoids, and in areas surrounding the photoreceptor somata (Fig. $3 A ; n=2$ ). In some sections, faint radial labeling that spanned the inner nuclear layer could be detected. In general, staining in the plexiform layers was more intense for NADPHd histochemistry than for NOS-like immunoreactivity (Table 1).

In the isolated retina preparation, intense NADPHd staining was observed in cells that were morphologically similar to Müller cells, as well as in the outer and inner limiting membranes, in photoreceptor inner segments and in the distal region of photoreceptor cell bodies (Fig. $3 B ; n=4$ ). Light staining was also observed in horizontal cells and in the inner plexiform layer (Fig. $3 B$ ). The presence of staining in presumptive amacrine cells or in the outer plexiform layer was difficult to resolve due to the intense staining of cells that morphologically resemble Müller cells. This pattern of NADPHd staining differs from that observed in the retinal section preparations. In the retinal section preparations, radially oriented processes, that might be Müller cell processes, were largely seen in the outer plexiform layer and outer nuclear layer. In contrast, in the isolated retina preparation, Müller-like cells were stained from the outer limiting membrane to the inner limiting membrane. Note that the isolated retina preparation preserves retinal morphology to a greater degree than the retinal section preparation. Therefore, it is possible to identify clearly the cellular structures that are NADPHd positive. Using the isolated retina preparation as an aid to identify cell types that are NADPHd positive, we may conclude that horizontal cells and Müller cells contribute to the staining of the outer plexiform/horizontal cell region observed in the retinal section preparation.

Previous studies in salamanders have shown that Müller cells have a thick radial stalk that extends across the retina; tangential processes emanate from this stalk to surround somata in the inner nuclear layer and apical processes envelope photoreceptor somata (Sarantis and Mobbs, 1992). We used a glial cell marker to test the possibility that the NOS-like immunoreactivity surrounding photoreceptor somata was localized to Müller cells, and to confirm that the transretinal radially oriented processes seen with NADPHd histochemistry were Müller cells. As shown in Figurc $4 A$, labeling the salamander retina with anti-GFAP (glial fibrillary acidic protein), a glial cell marker (Bignami and Dahl, 1977), revealed radially oriented cells with large end-feet in the ganglion cell layer, and basket-like processes surrounding nuclei both in the inner nuclear layer and in the outer nuclear layer $(n=4)$. Based on location, morphology, and immunoreactivity to GFAP, the processes surrounding photoreceptor somata were identified as part of the apical processes of Müller cells. Therefore, we suggest that the NOS-like immunoreactivity surrounding the photoreceptor somata is localized to the apical processes of Müller cells. 

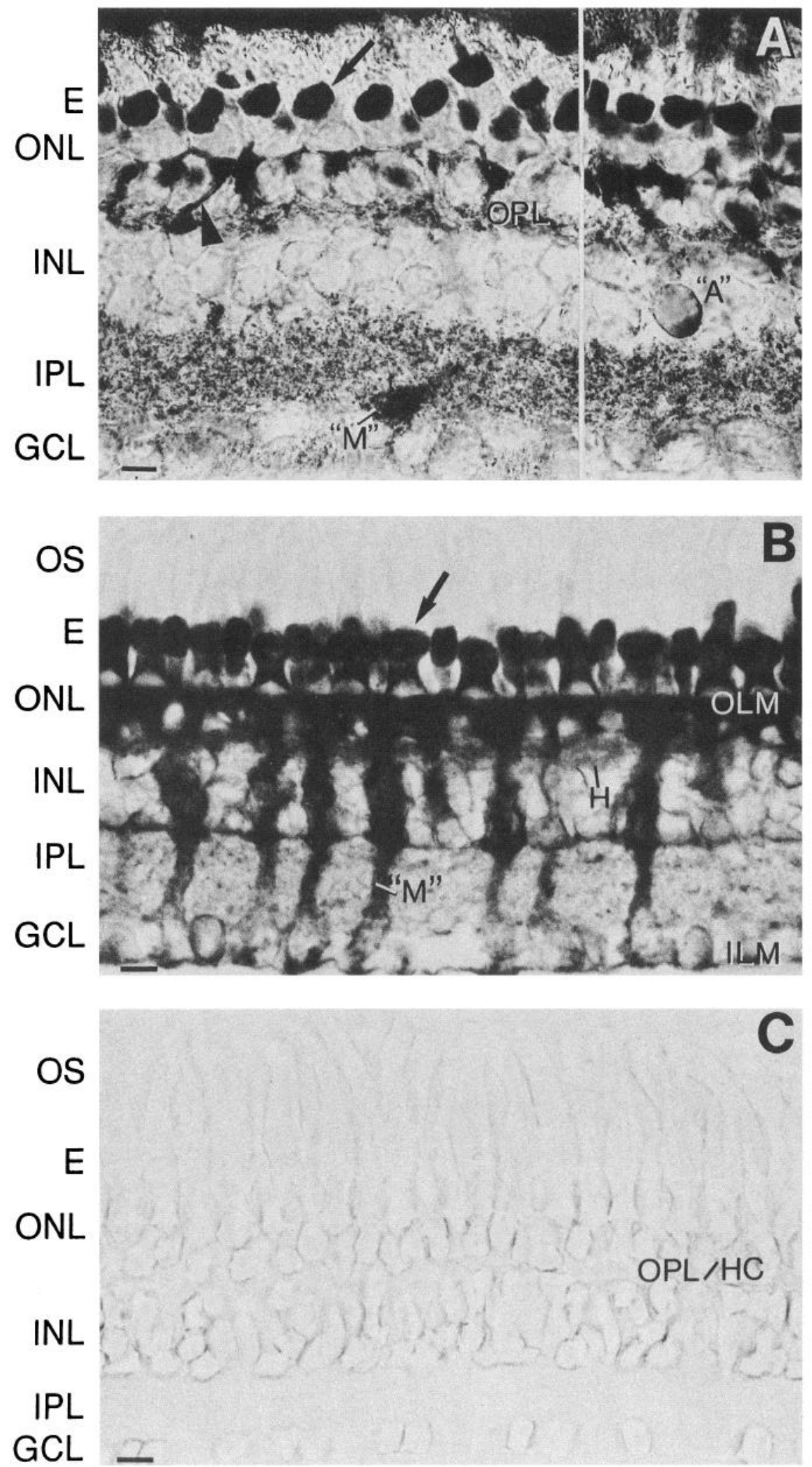

Figure 3. NADPHd staining in salamander retina. $A$, Pattern of NADPHd staining in the retinal section preparation. Ellipsoids (arrow), areas around nuclei in ONL (arrowhead), OPL, an occasional presumptive amacrine cell (" $A$ ") in INL, and IPL are stained. Staining is also apparent in thick processes ending at the GCL; these processes may be Müller cell (“ $M$ ") endfeet. Faint radial staining through the INL can be seen in this section. $B$, Pattern of NADPHd staining in isolated retina preparation. There is intense staining in ellipsoids (arrow), IS myoids, OLM, ILM, OPL, areas around nuclei in ONL, and thick radial processes that extend from OLM to ILM that are likely to be Müller cells (" $M$ "). The IPL and horizontal cells $(H)$ are lightly stained. $C$, Illustrates the lack of NADPHd staining in the isolated retina preparation in the absence of NADPH. $I L M$, inner limiting membrane; $O L M$, outer limiting membrane; $O S$, outer segments; $I S$, inner segments; $H C$, horizontal cell layer. Other abbreviations are as in Figure 1. Scale bars, $10 \mu \mathrm{m}$.
NADPHd histochemistry and GFAP immunoreactivity were tested in the same retinal sections to provide further support for the suggestion that Müller cells express an NOS-like enzyme $(n=3)$. For these studies, NADPHd histochemistry was performed using the isolated retina preparation. The retina was then adhered to filter paper to facilitate orientation during the embedding process. The retina was sectioned and processed for GFAP immunoreactivity as described in Materials and Methods. Figure $4 B$ shows the dark staining of NADPHd histochemistry in ellipsoids, areas surrounding photoreceptor nuclei, outer 


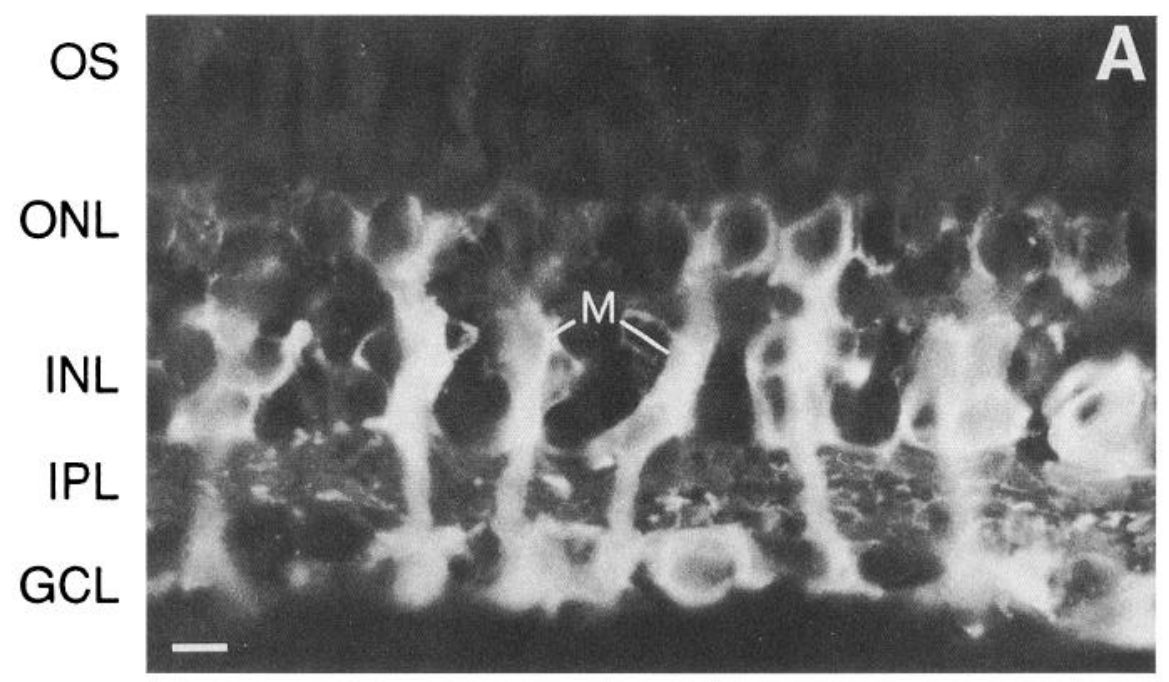

Figure 4. Localization of GFAP immunoreactivity and NADPHd staining in the salamander retina. $A$, Binding of anti-GFAP labeling visualized with LRSC. Cells that are morphologically indistinguishable from Müller cells $(M)$ are labeled from end-feet in the GCL to the processes surrounding nuclei in ONL. $B$ and $C$, Paired photomicrographs of the same retinal section showing the overlap between NADPHd staining $(B)$ and anti-GFAP binding $(C)$ in radial processes of Müller cells $(M)$. NADPHd staining was conducted in the isolated retina preparation that was then processed for anti-GFAP immunohistochemistry. $B$, Note that NADPHd staining of Müller cell processes is most intense in ONL, OPL, and INL. Only faint staining is detected in the IPL and GCL. $C$, In contrast, GFAP immunoreactivity in the same Müller cell processes is restricted to the GCL, IPL, and INL. Abbreviations are as in Figures 1 and 3. Scale bars, $10 \mu \mathrm{m}$ (bar in $C$ is for $B$ and $C$ ).
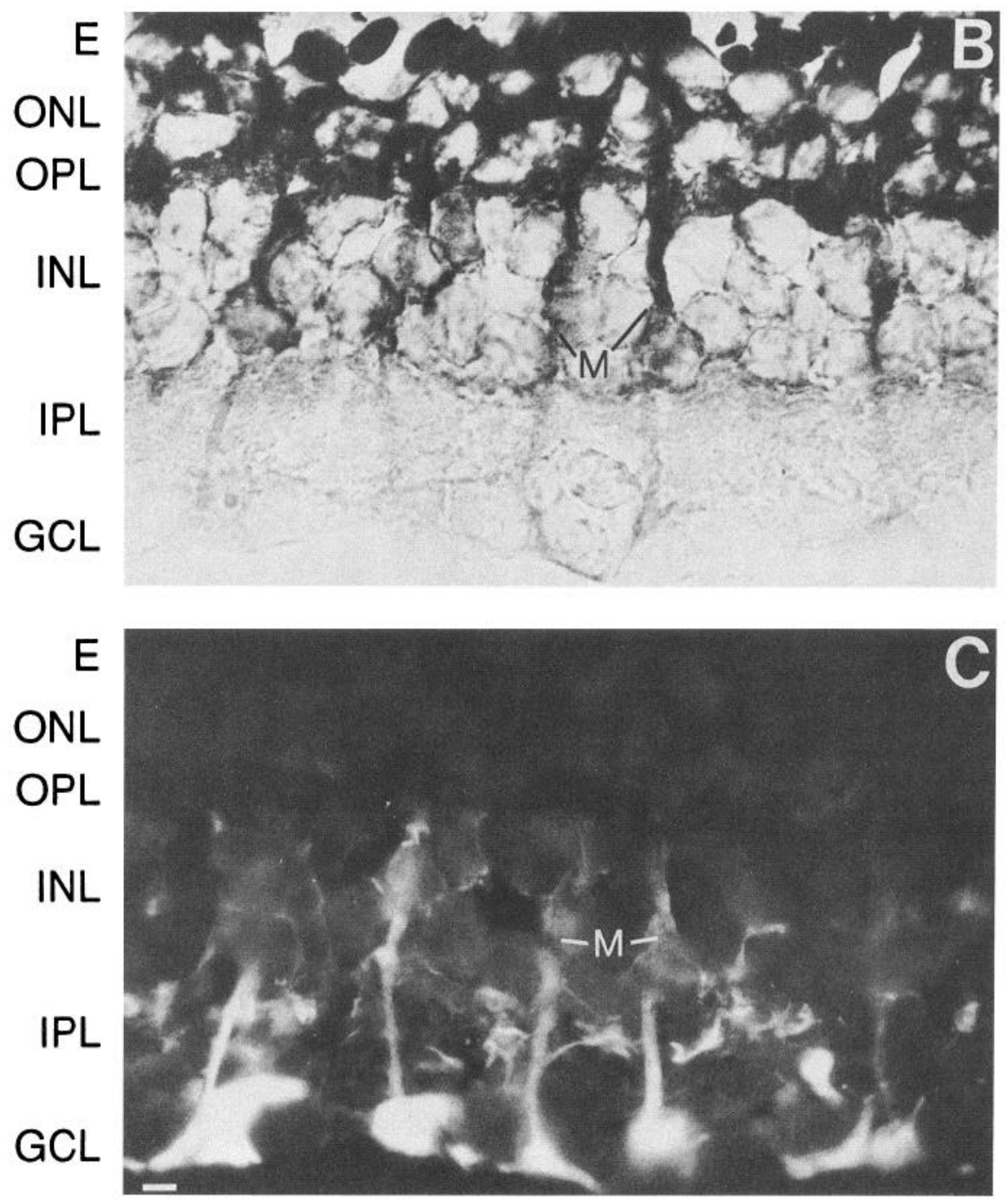

plexiform layer, and radial processes of Müller cells. Staining in the Müller cell processes was most prominent through the inner nuclear layer to the outer nuclear layer. Only faint staining of the radial processes can be seen in the inner plexiform and ganglion cell layers. Comparing the same field under fluores- cence shows that GFAP immunoreactivity overlaps with the NADPHd staining in the inner retina (Fig. 4C). GFAP immunoreactivity was most prominent in the endfeet and radial processes that extend through the inner plexiform layer and into the inner nuclear layer. It was our impression that NADPHd 
staining obscured the fluorescence due to GFAP immunoreactivity in the outer nuclear and outer plexiform layer and that the immunohistochemical procedures diminished NADPHd staining in the inner retina (compare Figs. $3 B, 4 B$ ). As a result of this apparent interference between the two labeling procedures, our data do not demonstrate simultaneous GFAP immunoreactivity and NADPHd staining in an individual process surrounding the photoreceptor somata. However, the overlap of both GFAP immunoreactivity and NADPHd histochemistry in the radial processes shows that Müller cells are NADPHd positive. This observation, together with GFAP immunoreactivity to the apical portion of the Müller cell (Fig. $4 A$ ) and NOSlike immunoreactivity to arcas surrounding photorcceptor nuclei (Fig. 1A), is consistent with the presence of NOS in Müller cells of the salamander retina.

\section{NOS localization in goldfish retina}

In the goldfish retina, NOS-like immunoreactivity was localized to radial processes extending from the outer plexiform layer to the inner limiting membrane; NOS-like immunoreactivity was also observed in a subset of presumptive amacrine cells, in an occasional somata in the ganglion cell layer, and in the outer limiting membrane $(n=4)$. Additional staining was observed in what appear to be synaptic terminals of On-bipolar cells (Sakai and Ball, 1994). In some sections faint labeling of horizontal cells and of punctate structures at the inner margin of the outer plexiform layer was detected. In the goldfish retina, labeling with the NOS antiserum was somewhat variable. In some sections, only presumptive amacrine cells were labeled and in others only radial processes. Figure $5 A$ shows a retinal section in which radial processes, large patches at the junction between the inner plexiform layer and ganglion cell layer, cells in both the inner nuclear and ganglion cell layers, and punctate regions at the inner margin of the outer plexiform layer are clearly labeled. Figure $5 B$ shows NOS-like immunoreactivity in radial processes and at the outer limiting membrane, whereas Figure $5 C$ shows labeling of a presumptive amacrine cell. Specific staining of the photoreceptor ellipsoids was variable, due in part to the autofluorescence of this cellular compartment in the absence of the antiserum (Fig. $5 D$ ). In the absence of the primary antibody, a fluorescent signal in other cell types or compartments was not detected.

The morphology and location of the radial processes and the staining at the outer limiting membrane suggested that NOSlike immunoreactivity was localized to Müller cells. To test this possibility, we double labeled retinal sections with NOS antiserum and anti-vimentin (a Müller cell and $\mathrm{H} 1$ horizontal cell marker in goldfish; Dräger, 1983; Vaughan and Lasater, 1990). In Figure $6, A$ and $B$ show the same retinal section labeled with the two antibodies. Both antibodies were colocalized to the identical radial processes and endfeet extensions in the ganglion cell layer, confirming that NOS-like immunoreactivity occurs in goldfish Müller cells $(n=2)$.

\section{NADPH diaphorase localization in goldfish retina}

In the retinal section preparations, intense NADPHd staining was observed in photoreceptor ellipsoids, the inner plexiform layer, and the outer plexiform/horizontal cell region. At the proximal margin of the inner plexiform layer, patches of more intense staining can be resolved. These patches may represent On-bipolar cell terminals (Sakai and Ball, 1994). To a lesser degree, cells in the ganglion cell layer, a subset of presumptive amacrine cells, and the outer limiting membrane were also stained $(n=4)$. Figure $7 A$ is an example of the NADPHd staining pattern in goldfish retinal section preparations. The inset to Figure $7 \mathrm{~A}$ shows labeling of processes extending distally to form the outer limiting membrane. These processes most likely originate from Müller cells.

In the isolated retina preparation, NADPHd staining was readily observed in photoreceptor ellipsoids and a subset of presumptive amacrine cells. Staining of horizontal cells, the outer limiting membrane, and radial processes extending through the outer nuclear layer was more pronounced in the isolated retina preparation than the retinal section preparation $(n=7)$. Staining of the horizontal cell layers was most apparent just proximal to the outer plexiform layer, suggesting that these cells are most likely the $\mathrm{H} 1$ cone horizontal cells. In some sections, staining was observed in two layers proximal to the outer plexiform layer, suggesting that the $\mathrm{H} 2 / \mathrm{H} 3$ cone horizontal cells also contribute to the NADPHd labeling (for morphology of goldfish horizontal cells, see Stell and Lightfoot, 1975; Marc et al., 1978). Staining was also observed just distal to the outer plexiform layer. In some sections, this staining appeared punctate. Figure $7 B$ shows typical NADPHd staining in the isolated retina preparation. In the isolated retina preparation, staining in the inner retina was significantly fainter than in the retinal section preparation. This difference is readily discerned when comparing Figure $7 A$ to $7 B$. It was our impression that penetration into the inner retina was more limited in the fixed isolated retina preparation. However, when the NADPHd reaction was carried out for longer times the inner plexiform layer as wcll as occasional somata in the ganglion cell layer were also stained in the isolated retina preparation (data not shown). The difference in the staining patterns obtained with these two methods of tissue preparation was not a result of the plastic embedding process used in the isolated retina preparation. In the absence of plastic embedding, retinal slices from isolated retinas that were reacted for NADPHd activity showed the same pattern of staining as in the isolated retina preparation (data not shown). Therefore, we postulate that in the isolated retina preparation diffusion of NBT or NADPH may be restricted. Figure $7 C$ shows the lack of staining in the absence of NADPH.

In the goldfish retina, regardless of the tissue preparation used to examine NADPH staining, more cell types and processes showed NADPHd staining than NOS-like immunoreactivity (Table 1). Additionally, in Müller cells there were differences in the subcellular localization of NOS-like immunoreactivity and NADPHd staining. Whereas NOS-like immunoreactivity was observed in Müller cell end-feet and in radial processes in the proximal retina, NADPHd staining was observed in the distal portion of these glia. Together, these observations show that NADPHd staining has a much wider cellular distribution in the retina than does NOS-like immunoreactivity. In addition, staining patterns for NADPHd differed depending on the method of tissue preparation.

\section{NOS and NADPH diaphorase localization in catfish retina}

In the catfish retina, NOS-like immunoreactivity was detected in an occasional cell in the inner nuclear layer $(n=2$; data not shown). Lateral processes emanating from these cells suggested that they were amacrine cells. Photoreceptor ellipsoids were also lightly labeled. However, it was difficult to determine whether this labeling was specific due to the autofluorescence of this cellular compartment. In the absence of the NOS antiserum no 


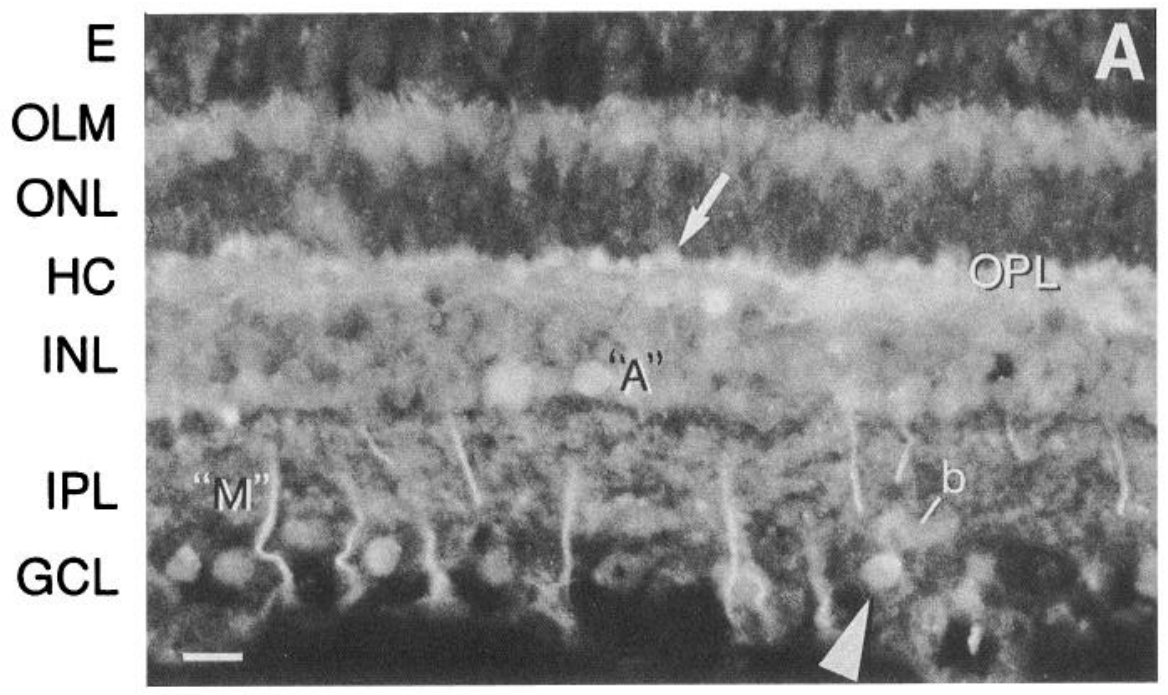

Figure 5. NOS-like immunoreactivity in goldfish retina. $A-C$, Binding of NOS antiserum visualized with FITC. $A$ illustrates binding of the antiserum to an occasional presumptive amacrine cell (" $A$ ") in INL and somata in GCL (arrowhead), and to radial processes indicative of Müller cells (" $M$ "). Punctate labeling at the inner margin of the OPL (arrow) and light labeling in the horizontal cell layer is also shown. Large immunoreactive patches suggestive of On-bipolar synaptic terminals $(b)$ were also detected. $B$ illustrates a section in which labeling is detectable in the OLM and radial processes extending from the GCL to the OPL/ONL. C illustrates a section in which an occasional cell in the INL (" $A$ ") is labeled. $D$, in absence of the NOS antiserum there is no detectable labeling except at the photoreceptor ellipsoids. Abbreviations are as in Figures 1 and 3. Scale bars, $10 \mu \mathrm{m}$.
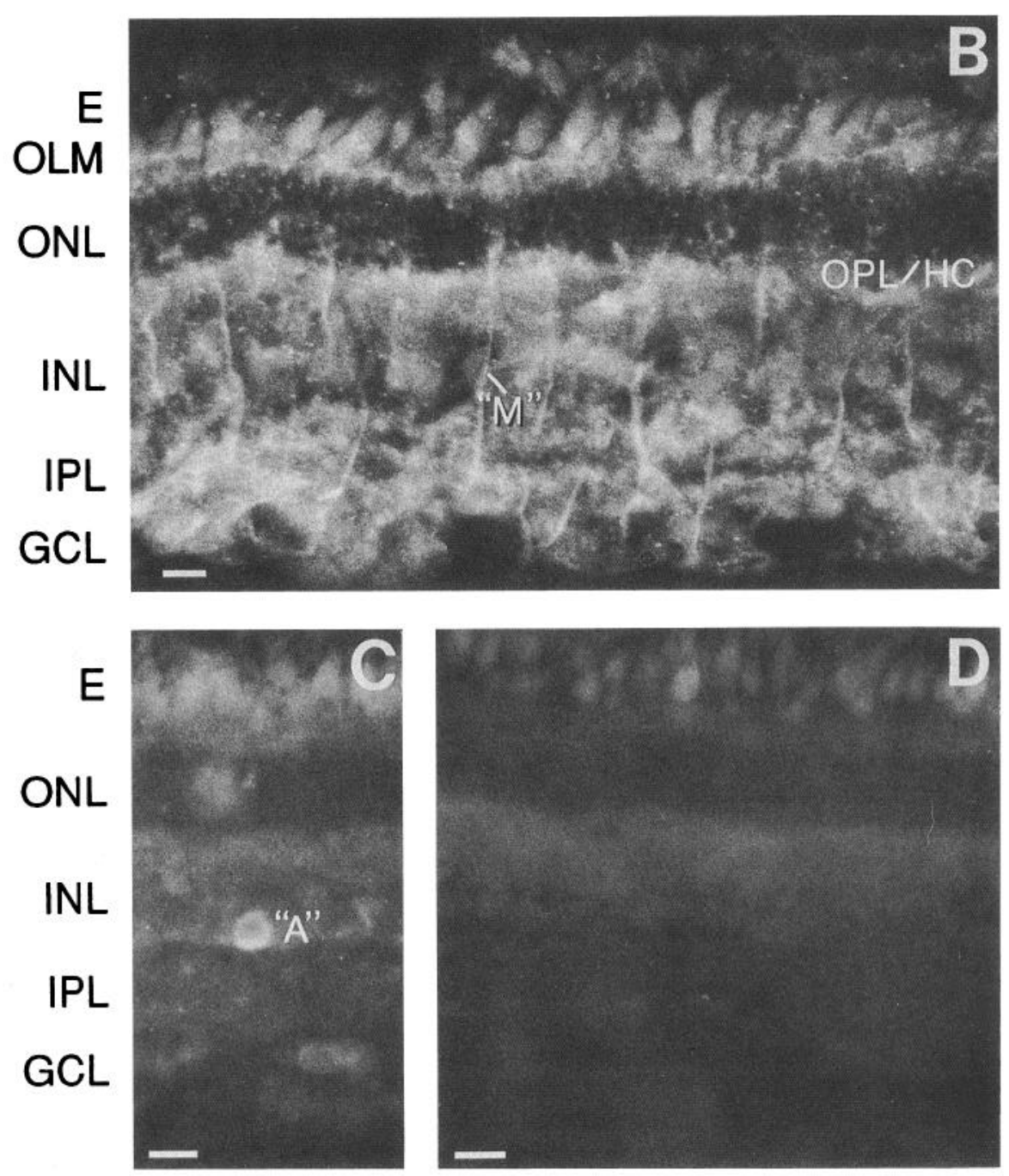

detectable labeling or fluorescence was observed in retinal cells other than photoreceptors.

In the isolated retina preparation of the adult catfish, NADPHd staining was clearly evident in photoreceptor ellipsoids, cells in the ganglion cell layer, blood vessels and cells morphologically indistinguishable from Müller cells $(n=7)$. In Figure $8, A$ and $B$ show examples of NADPHd staining in the adult catfish isolated retina preparation. In the absence of NADPH there was no detectable staining (Fig. $8 C$ ). In retinal whole-mounts, NADPHd staining of blood vessels at the vitreal surface of the 

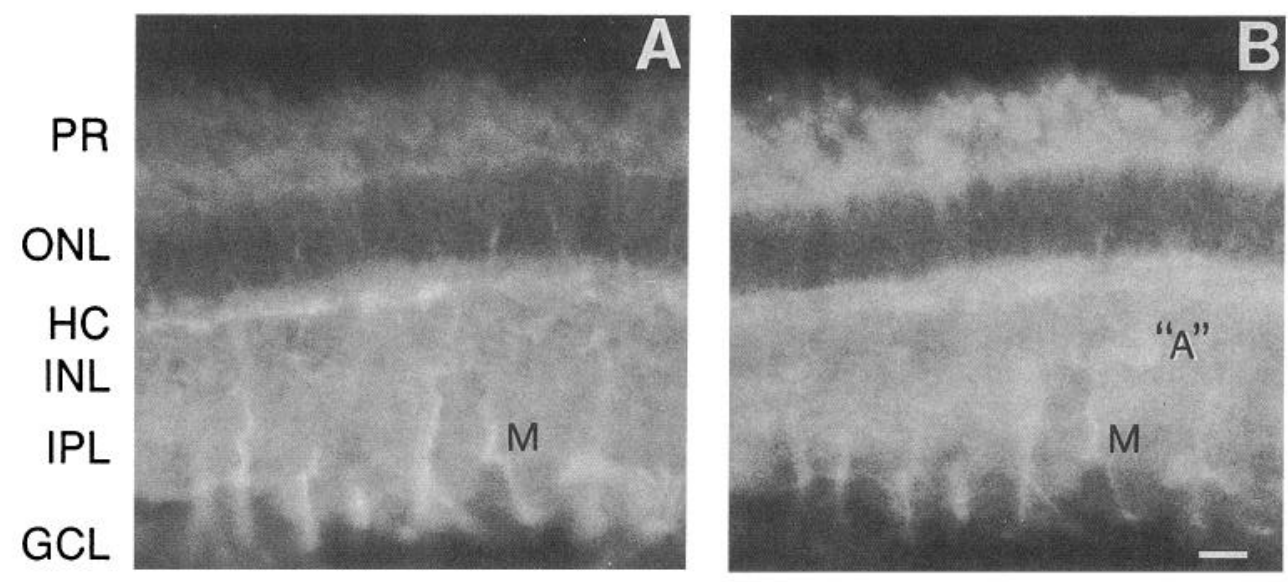

Figure 6. Colocalization of vimentin and NOS-like immunoreactivity in paired retinal sections from goldfish. $A$, Goldfish retinal section labeled with anti-vimentin visualized with rhodamine. Note labeling in radial processes $(M)$ extending through the INL to the GCL and in the horizontal cell layer. $B$, Goldfish retinal section labeled with anti-NOS visualized with FITC. Note labeling of the same processes $(M)$ as found in $A$. Also note faint labeling of presumptive amacrine cell (" $A$ ") in the INL. $P R$, photoreceptor inner and outer segments. Other abbreviations are as in Figures 1 and 3. Scale bar, $10 \mu \mathrm{m}$.

retina was readily apparent (Fig. $8 D$ ). As in goldfish and salamander, these observations show that NADPHd staining has a much wider cellular distribution in the retina than does NOSlike immunoreactivity (Table 1).

To obtain better morphology, juvenile catfish were used for retinal section and isolated retina preparations $(n=1)$. In the retinal section preparation, NADPHd staining in these younger animals was observed in both plexiform layers, a subset of cells in the inner nuclear layer, an occasional cell in the ganglion cell layer, and photoreceptor ellipsoids. Staining adjacent to the outer plexiform layer suggests the presence of labeling in horizontal cells. Figure $9 \mathrm{~A}$ shows an example of this pattern of staining. Based on size and morphology the NADPHd-positive cells in the ganglion cell layer appear to be ganglion cells and not displaced amacrine cells. In isolated retina preparations obtained from juvenile catfish, NADPHd staining was observed in presumed Müller cells, photoreceptor ellipsoids, and blood vessels (Fig. $9 B ; n=3$ ). These observations show that in the retinas of both adult and juvenile catfish staining patterns for NADPHd differed depending on the method of tissue preparation.

\section{Discussion}

The results presented here show that markers for NOS are localized to a number of different retinal neurons including amacrine cells, somata in the ganglion cell layer, photoreceptor ellipsoids, and horizontal cells. Of particular interest is the novel finding that markers for NOS are also localized to Müller cells in all three species examined. Evidence supporting the localization of NOS to these retinal glia includes NADPHd staining of Müller cells in all three species, colocalization of NOS-like immunoreactivity with that of vimentin in goldfish, and localization of both NOS-like and GFAP immunoreactivity to Müller cells in salamander.

\section{NADPHd histochemistry and NOS immunocytochemistry}

Our results show that, although there was overlap in the staining patterns between NOS-like immunoreactivity and NADPHd staining, more cell types were positive for NADPHd. Similar observations were made in the rat retina (Yamamoto et al., 1993) and in the adrenal gland (Dawson et al., 1991), demonstrating that there is not always a one-to-one correspondence between NOS-like immunoreactivity and NADPHd activity. The greater degree of NADPHd staining compared to NOS-like immunoreactivity may reflect the specificity of the NOS antiserum, which is directed against only one NOS isoform, com- pared to NADPHd staining, which labels all known NOS isoforms (Dawson et al., 1991; Mitchell et al., 1992; Tracey et al., 1993). As a more ubiquitous marker for NOS, NADPHd staining in the retina may indicate the presence of other NOS-like enzymes that are not recognized by the antibody. Alternatively, the greater degree of staining with the NADPHd histochemistry may result from the presence of other oxidative enzymes as has been suggested to occur in the adrenal gland (Dawson et al., 1991).

\section{Species differences in NOS-like immunoreactivity and NADPHd activity}

As shown above, markers for NOS were localized to Müller cells, photoreceptor ellipsoids, and a subset of presumptive amacrine cells in all three species examined. However, despite these similarities, each species displayed a unique staining pattern for the NOS markers (see Table 1). These species differences are perhaps best exemplified by the relative staining in horizontal cells. In goldfish, horizontal cells were robustly stained for NADPHd activity and only lightly labeled by the NOS antiserum, whereas in salamander, horizontal cells were lightly stained for NADPHd activity and not by the NOS antiserum. Last, in the adult catfish, neither NOS marker consistently labeled horizontal cells. These observations indicate the diversity of the cellular localization of NOS in the retinas of lower vertebrates.

\section{Tissue preparation and NADPHd staining}

In this study, we found differences in NADPHd staining between isolated retina and retinal section preparations (see Materials and Methods). One of the major differences between these two preparations was the relative staining of the Müller cells. In the isolated retina preparation, Müller cells were clearly stained across the entire retina in catfish and salamander, whereas in the retinal section preparation the staining of Müller cells was much less obvious. Previous studies by others evaluating NADPHd activity were done with retinal section preparations. This may explain why NADPHd staining in Müller cells was not recognized earlier. At this time we cannot account for the differences in the staining patterns observed in the two tissue preparations used here. It is unlikely that the longer incubation times in the reaction mixture of the isolated retina preparations compared to those of the retinal section preparations produced the differences in staining patterns. Longer or shorter incubation 
Figure 7. NADPHd staining in goldfish retina. $A$, Pattern of NADPHd staining in the retinal section preparation. There is robust staining in ellipsoids (which is evident in the inset) OPL/HC, occasional cell bodies in INL and GCL (arrowhead), and irregular shaped patches that occur at regular intervals in the IPL $(b)$. Light staining is seen at the OLM. In some sections, stained radial processes extending through the ONL were also observed. Inset shows stained processes that are morphologically similar to Müller cells (" $M$ ") extending through the ONL that fuse with the OLM $(1475 \times$ magnification). $B$, Pattern of NADPHd staining in isolated retina preparation. There is intense staining of $\mathrm{H} 1$ and $\mathrm{H} 2 / \mathrm{H} 3$ horizontal cells $(H C)$. Staining is also seen in ellipsoids (arrows), OLM, presumptive amacrine cell somata (" $A$ ") in INL, processes (" $M$ ") that extend from the OPL/INL to the OLM, and in the distal OPL, which may represent staining in photoreceptor terminals. $C$, Illustrates the lack of NADPHd staining in the retinal section preparation in the absence of NADPH. $D$, Illustrates the lack of NADPHd staining in the isolated retina preparation in the absence of NADPH. Abbreviations are as in Figures 1, 3, and 6. Scale bars, 10 $\mu \mathrm{m}$.
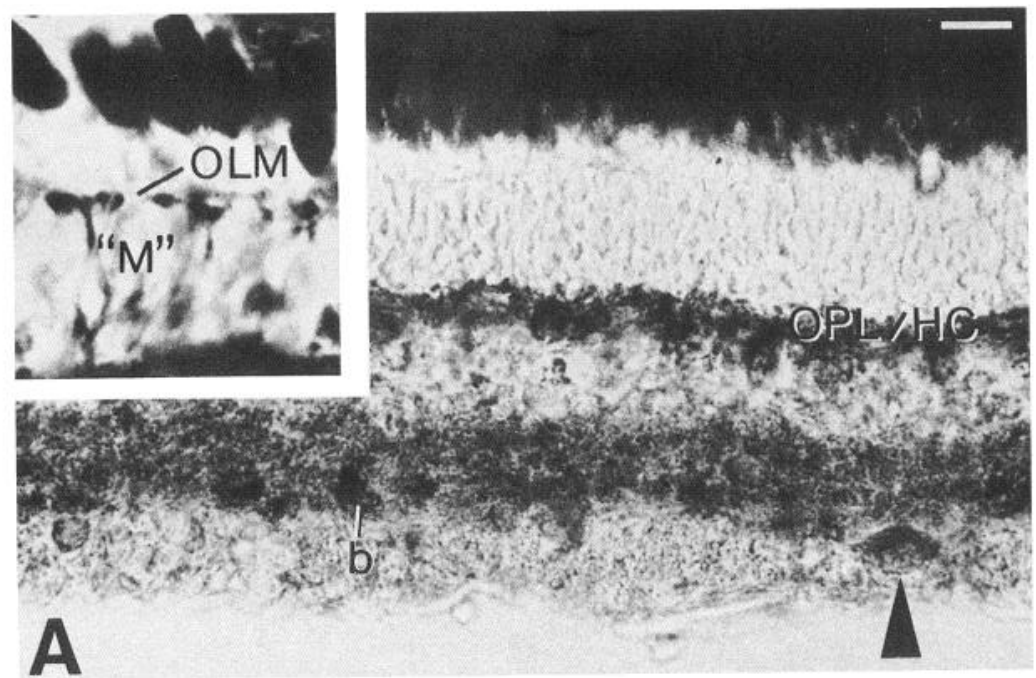

INL

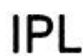

GCL

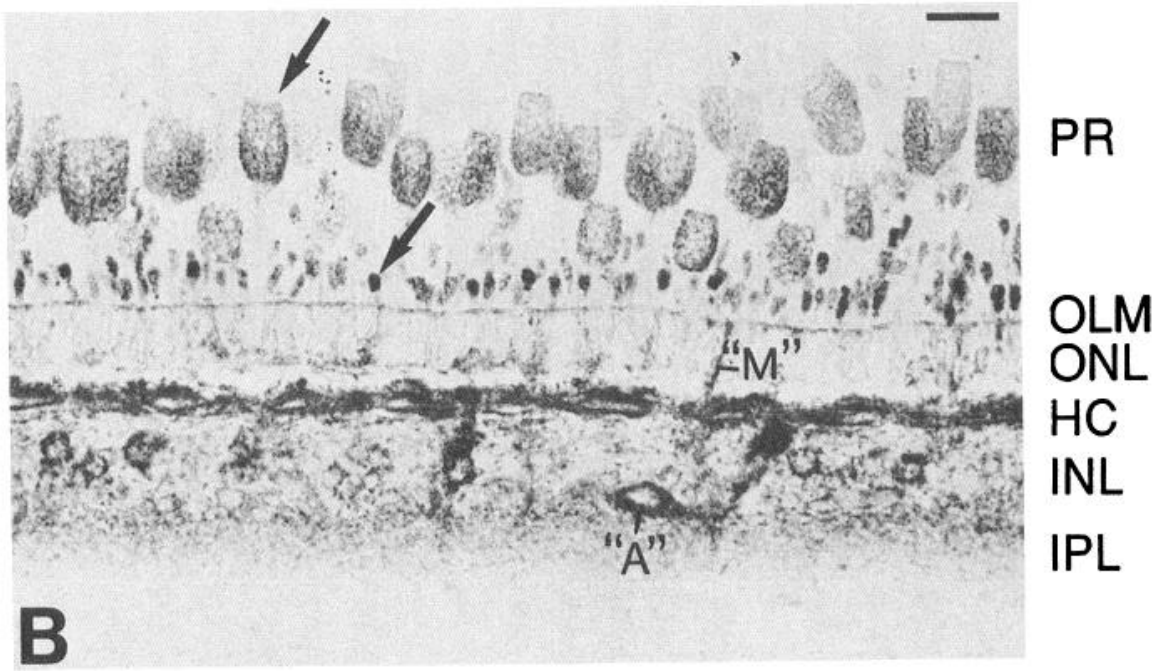

PR

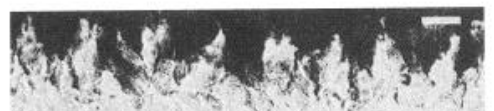

ONL

OPL

INL

IPL

GCL

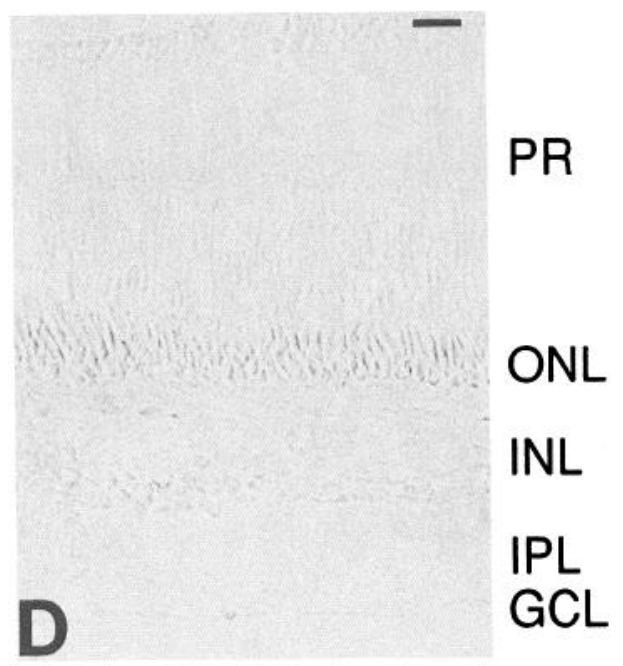

times of the retinal sections served only to intensify or weaken, respectively, the degree of staining rather than alter the pattern of staining. However, it is conceivable that incorporation of either the substrate NADPH or the dye nitro blue tetrazolium into the Müller cell end-feet and processes in the inner retina requires that these glial cells are intact. These observations show that the method of tissue preparation can modify the results of NADPHd histochemistry. 

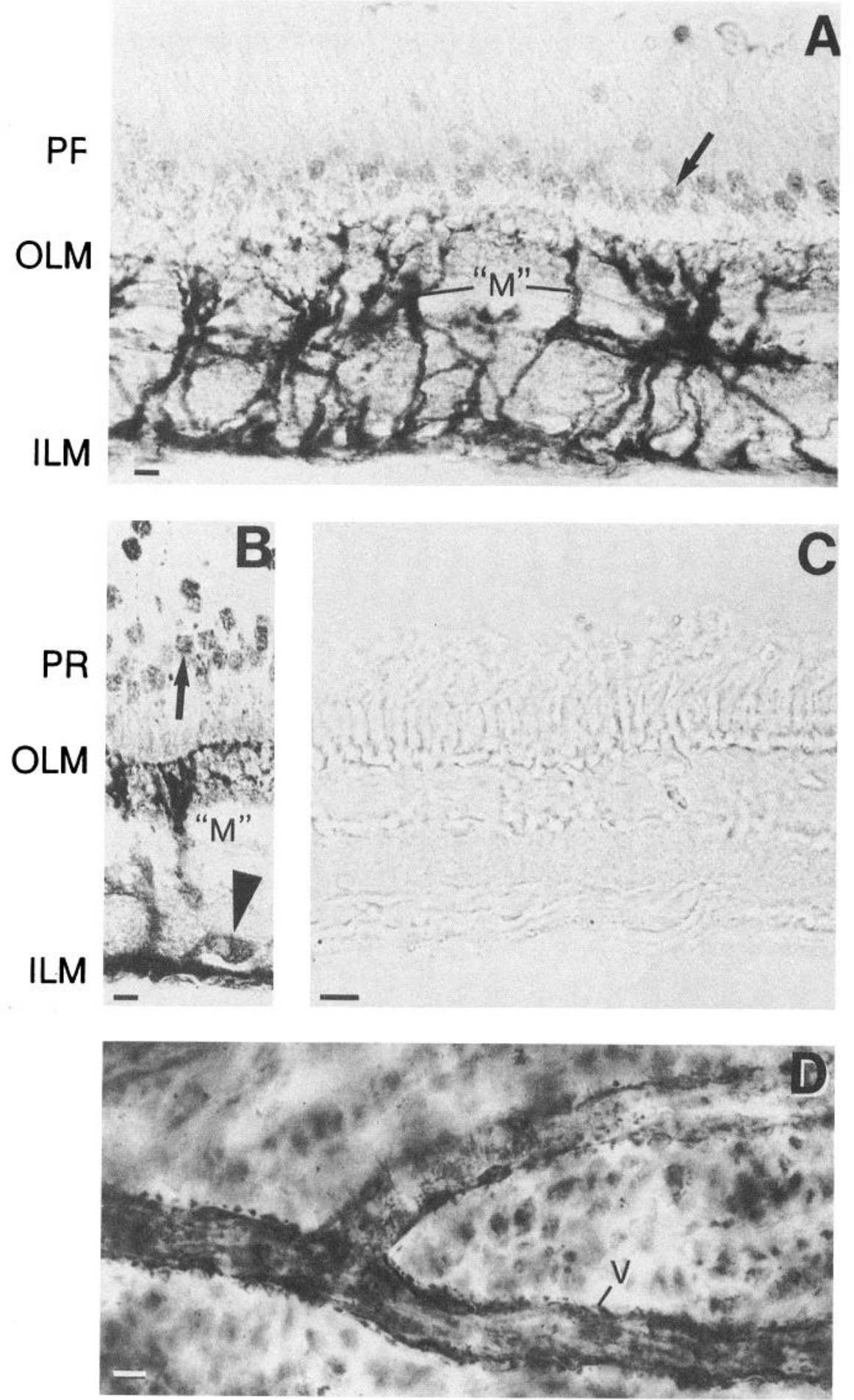

Figure 8. NADPHd staining in the adult catfish retina. $A$ and $B$, Pattern of NADPHd staining in the isolated retina preparation. Cells morphologically indistinguishable from Müller cells (" $M$ ") show robust staining. NADPHd staining was also detected in cell bodies in the GCL (arrowhead) and in ellipsoids (arrows). $C$, No staining is apparent in the isolated retina preparation in the absence of NADPH. $D$, In retinal whole mounts, NADPHd staining is apparent in a blood vessel $(V)$ located at the vitreal surface of the retina. Abbreviations are as in Figures 1, 3, and 6. Scale bars, $10 \mu \mathrm{m}$.

\section{Functional implications of NOS in retinal neurons}

The localization of NOS to a variety of retinal neuron, as well as Müller cells, suggests that NO might serve as an extracellular and/or intracellular messenger molecule in the retina. Several studies suggest that NO can modify the electrical behavior and responses of retinal neurons. However, a distinct functional role of NO in the retina remains to be demonstrated.

In photoreceptors, the presence of an NO-sensitive guanylyl cyclase has been reported (Margulis et al., 1992). Because cGMP is the candidate second messenger of phototransduction (Fesenko et al., 1985), NO activation of guanylyl cyclase could have profound effects on light-induced responses. In isolated toad rod photoreceptors, intracellular application of high concentrations of the NO donor sodium nitroprusside reportedly depolarizes the plasma membrane and alters light-evoked responses (K.-F. Schmidt et al., 1992). NO donors have also been reported to alter ADP-ribosylation of several photoreceptor pro- 

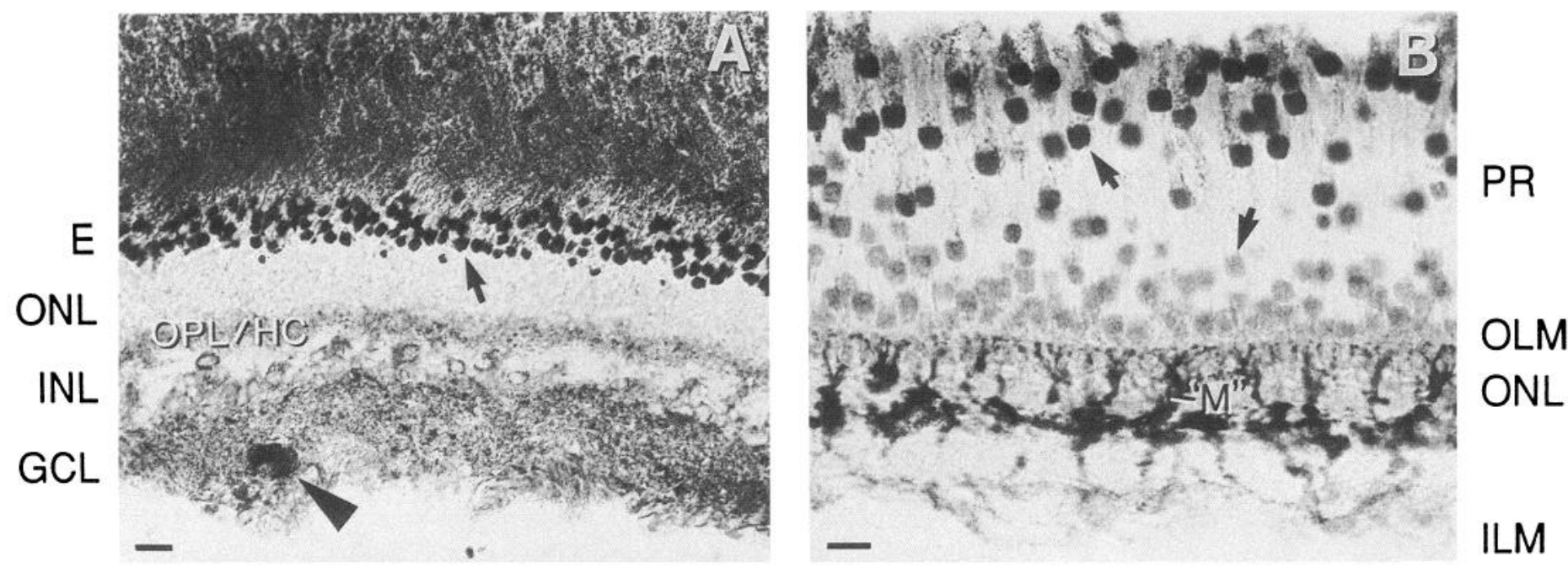

Figure 9. NADPHd staining in the juvenile catfish retina. A, Pattern of NADPHd staining in the retinal section preparation. There is robust staining in ellipsoids (arrow), OPL/HC, IPL, and occasional cell bodies in INL and GCL (arrowhead). B, Pattern of NADPHd staining in the isolated retina preparation. There is robust staining of rod and cone ellipsoids (arrows) and of radial processes extending from the ILM to the OLM that resemble Müller cells (" $M$ '). Abbreviations are as in Figures 3 and 6. Scale bars, $10 \mu \mathrm{m}$.

teins including transducin (Ehret-Hilberer et al., 1992; Pozdnyakov et al., 1993).

In horizontal cells, modulation of electrical coupling can alter receptive field sizes of these neurons and thus influence the lateral spread of light-induced responses in the retina. Injection of the NO precursor $l$ - arginine into horizontal cells has been reported to reduce electrical and dye tracer coupling, whereas intracellular injection of NOS inhibitors promotes coupling (Miyachi et al., 1990; Mills and Massey, 1993). Consistent with these observations, both sodium nitroprusside and the cGMP analog 8-bromo-cGMP have been shown to reduce coupling in pairs of horizontal cells isolated from catfish (DeVries and Schwartz, 1989). Together, these observations suggest that both NOS and soluble guanylyl cyclase are present in horizontal cells.

In all species so far examined, subsets of amacrine cells have been identified as either NOS-like immunoreactive and/or NADPHd positive (Sandell, 1985; Sagar, 1986; Vaney and Young, 1988; Cobcroft et al., 1989; Mitrofanis, 1989; Provis and Mitrofanis, 1990; Sagar, 1990; Dawson et al., 1991; Straznicky and Gabriel, 1991; Yamamoto et al., 1993). To date, the functional significance of NOS in amacrine cells is not understood. However, it is likely that amacrine cells are a source of NO and provide this gas to nearby neurons.

NOS-like immunoreactivity has recently been reported in Onbipolar cells of the goldfish retina (Sakai and Ball, 1994). Further, in both On-bipolar and ganglion cells, NO donors increase the conductance through presumptive cGMP-gated channels, suggesting that these retinal neurons contain soluble guanylyl cyclase (Nawy and Jahr, 1991; Shiells and Falk, 1992; Ahmad et al., 1994). The functional significance of the cGMP-gated channel in ganglion cells is currently unknown. However, NO donors depolarize ganglion cells presumably by elevating intracellular levels of cGMP (Ahmad et al., 1994). Perhaps this depolarization is sufficient to reduce the voltage-dependent $\mathrm{Mg}^{2+}$ block of NMDA receptors (Mayer et al., 1984; Nowak et al., 1984; Diamond and Copenhagen, 1993) and thus provide a pathway for NO to modulate glutamatergic responses in ganglion cells. Alternatively, NO could directly block NMDA re- ceptors as has been shown in cultured neurons (Manzoni et al., 1992).

\section{Functional implications of NOS in Müller glial cells}

The significance of NOS in Müller cells is unknown. However, because Müller cells extend radially across the retina from photoreceptors to ganglion cells, it is possible that these glia provide NO to the potential target cells that occur in all retinal layers. Additionally, Müller cell processes and end-feet have been shown to surround blood vessels in the retinas of some species (Hollander et al., 1991). In some teleost species, there is an extensive network of vitreal blood vessels that lies proximal to the inner limiting membrane (Collin, 1989). These observations suggest that Müller cells are in a position to regulate local retinal blood flow by communicating with endothelial cells (Newman et al., 1984; Clark and Mobbs, 1992). NO has been proposed to link the activities of neurons, glia, and endothelial cells in the regulation of blood flow (see review, see Barres et al., 1991; Goadsby et al., 1992; Iadecola, 1992). Alternatively, NOS could play a role within Müller cells in the regulation of intracellular events. Indeed, sodium nitroprusside in the rat retina increases cGMP immunoreactivity in radial processes that resemble Müller cells (Berkelmans et al., 1989; see Fig. 2), suggesting the presence of soluble guanylyl cyclase in these glia and that Müller cells are both targets and sources of NO.

Previously, NOS has been localized to some glial cell types of the CNS but not to glia of the retina (Murphy et al., 1990; for review, see Murphy et al., 1993). In cultured astrocytes, the presence of the inducible isoform of NOS (iNOS) has been well documented (Galea et al., 1992; Simmons and Murphy, 1992), while the presence of the constitutive isoform (cNOS) rests on indirect observations (Agullo and Garcia, 1992). Some support for the presence of cNOS in CNS glia comes from the detection of weak cNOS-like immunoreactivity in Bergmann glia and astrocytes of the cerebellum (H. H. H. W. Schmidt et al., 1992).

In glia, it is unclear how cNOS might be activated. iNOS in glia can be activated by bacterial lipopolysaccharides in a manner similar to that observed in macrophages (Galea et al., 1992; 
Simmons and Murphy, 1992). One might also predict that the activity of cNOS in glia is regulated by the same mechanisms as described in neurons, in which glutamate binding to NMDA receptors, along with other ionotropic glutamate receptors, induces a $\mathrm{Ca}^{2+}$ influx that activates cNOS via calmodulin (for review, see Garthwaite, 1991). Consistent with this possibility, glutamate receptors, similar to those found on neurons, have been localized to glial cell membranes (for review, see Murphy and Pearce, 1987; Barres, 1991). Indeed, glutamate elevates intracellular levels of $\mathrm{Ca}^{2+}$ in cultured astrocytes (Cornell-Bell et al., 1990). In isolated Müller cells, aminoadipic acid, a glutamate analog, has also been shown to increase cytosolic levels of $\mathrm{Ca}^{2+}$ (Wakakura and Yamamoto, 1992). In glia, kainatc-type glutamate receptors have a relatively large $\mathrm{Ca}^{2+}$ conductance compared to their neuronal counterparts (Müller et al., 1992), and thus may play an important role in elevating cytosolic $\mathrm{Ca}^{2+}$ subsequent to NOS activation. It is likely that cNOS in glia is regulated by mechanisms similar to those found in neurons. However, it remains to be tested whether Müller cells express calmodulin and whether glutamate can promote $\mathrm{Ca}^{21 / \mathrm{cal}-}$ modulin activation.

\section{Conclusions}

NO is a short-lived molecule and thought to influence only the activities of adjacent cells or the cells in which it is generated. Therefore, it seems likely that cells capable of generating NO should be located throughout the retina to provide this gas to the postulated target cells. This is supported further by the localization of NOS markers to Müller cells, which form an extensive network that spans the retina from photoreceptors to ganglion cells. The release of a diffusible messenger molecule from such cells may effectively coordinate the activities of neurons throughout the retina. If NO released by Müller cells plays some role in modulating the cellular activities of nearby neurons, it will be interesting to determine the extracellular events that evoke NO production and subsequent release from these glia.

\section{References}

Agullo L, Garcia A (1992) Different receptors mediate stimulation of nitric oxide-dependent cyclic GMP formation in neurons and astrocytes in culture. Biochem Biophys Res Commun 182:1362-1368.

Ahmad I, Leinders-Zufall T, Kocsis JD, Shepherd GM, Zufall F, Barnstablc CJ (1994) Retinal ganglion cells express a cGMP-gated cation conductance activatable by nitric oxide donors. Neuron 12:155-165.

Arnold WP, Mittal CK, Katsuki S, Murad F (1977) Nitric oxide activates guanylate cyclase and increases guanosine $3^{\prime}: 5^{\prime}$-cyclic monophosphate levels in various tissue preparations. Proc Natl Acad Sci USA 74:3203-3207.

Ball AK, Dickson DH (1983) Displaced amacrine and ganglion cells in the newt retina. Exp Eye Res 36:199-213.

Barres BA (1991) New roles for glia. J Neurosci 11:3685-3694.

Berkelmans HS, Schipper J, Hudson L, Steinbusch HWM, de Vente J (1989) cGMP immunocytochemistry in aorta, kidney, retina and brain tissues of the rat after perfusion with nitroprusside. Histochemistry $93: 143-148$.

Bignami A, Dahl D (1977) Specificity of the glial fibrillary acidic protcin for astroglia. J Histochem Cytochem 25:466-469.

Bredt DS, Hwang PM, Snyder S (1990) Localization of nitric oxide synthase indicating a neuronal role for nitric oxide. Nature 347:768770.

Bredt DS, Hwang PM, Glatt CE, Lowenstein C, Reed RR, Snyder S (1991) Cloned and expressed nitric oxide synthase structurally resembles cytochrome P-450 reductase. Nature 351:714-718.
Brüne B, Lapetina EG (1989) Activation of a cytosolic ADP-ribosyltransferase by nitric oxide-generating agents. J Biol Chem 264:84558458.

Clark B, Mobbs P (i992) Transmitter-operated channels in rabbit retinal astrocytes studied in situ by whole-cell patch clamping. J Neurosci 12:664-673.

Cobcroft M, Vaccaro T, Mitrofanis J (1989) Distinct patterns of distribution among NADPH-diaphorase neurones of the guinea pig retina. Neurosci Lett 103:1-7.

Collin SP (1989) Topographic organization of the ganglion cell layer and intraocular vascularization in the retinae of two reef teleosts. Vision Res 29:765-775.

Cornell-Bell AH, Finkbeiner SM, Cooper MS, Smith SJ (1990) Glutamate induces calcium waves in cultured astrocytes: long-range glial signaling. Science 247:470-473.

Dawson TM, Bredt DS, Fotuhi M, Hwang PM, Snyder SH (1991) Nitric oxide synthase and neuronal NADPH diaphorase are identical in brain and peripheral tissues. Proc Natl Acad Sci USA 88:77977801 .

Deguchi T, Yoshioka M (1982) L-Arginine identified as an endogenous activator for soluble guanylate cyclase from neuroblastoma cells. $\mathbf{J}$ Biol Chem 257:10147-10151.

DeVries SH, Schwartz EA (1989) Modulation of an electrical synapse between solitary pairs of catfish horizontal cells by dopamine and second messengers. J Physiol (Lond) 414:351-375.

Diamond JS, Copenhagen DR (1993) The contribution of NMDA and non-NMDA receptors to the light-evoked input-output characteristics of retinal ganglion cells. Neuron 11:725-738.

Dräger UC (1983) Coexistence of neurofilaments and vimentin in a neurone of adult mouse retina. Nature 303:169-172.

Ehret-Hilberer S, Nullans G, Aunis D, Virmaux N (1992) Mono ADPribosylation of transducin catalyzed by rod outer segment extract. FEBS Lett 309:394-398.

Fesenko EE, Kolenikov SS, Lyubarsky AL (1985) Induction by cyclic GMP of cationic conductance in plasma membrane of retinal rod outer segment. Nature 313:310-313.

Galea E, Feinstein DL, Reis DJ (1992) Induction of calcium-independent nitric oxide synthase activity in primary rat glial cultures. Proc Natl Acad Sci USA 89:10945-10949.

Garthwaite J (1991) Glutamate, nitric oxide and cell-cell signalling in the nervous system. Trends Neurosci 14:60-67.

Goadsby PJ, Kaube H, Hoskin KL (1992) Nitric oxide synthesis couples cerebral blood flow and metabolism. Brain Res 595:167-170.

Hollander H, Makarov F, Dreher Z, van Driel D, Chan-Ling T, Stone J (1991) Structure of the macroglia of the retina: sharing and division of labour between astrocytes and Müller cells. J Comp Neurol 313: 587-603.

Hope BT, Michael GJ, Knigge KM, Vincent SR (1991) Neuronal NADPH diaphorase is a nitric oxide synthase. Proc Natl Acad Sci USA 88:281l-2814.

Iadecola C (1992) Does nitric oxide mediate the increases in cerebral blood flow elicited by hypercapnia? Proc Natl Acad Sci USA 89:39133916.

Manzoni O, Prezeau L, Marin P, Deshager S, Bockaert J, Fagni L (1992) Nitric oxide-induced blockade of NMDA receptors. Neuron 8:653662.

Marc RE, Stell WK, Bok D, Lam DMK (1978) GABA-ergic pathways in the goldfish retina. J Comp Neurol 182:221-246.

Margulis A, Sharma RK, Sitaramayya A (1992) Nitroprusside-sensitive and insensitive guanylate cyclases in retinal rod outer segments. Biochem Biophys Res Commun 185:909-914.

Marletta MA, Yoon PS, Iyengar R, Leaf CD, Wishnok JS (1988) Macrophage oxidation of $\mathrm{L}$-arginine to nitrite and nitrate: nitric oxide is an intermediate. Biochemistry 27:8706-8711.

Mayer ML, Westbrook GL, Guthrie PB (1984) Voltage-dependent block by $\mathrm{Mg}^{2+}$ of NMDA responses in spinal cord neurones. Nature 309:261-263.

Mills SL, Massey SC (1993) Invest Ophthalmol Vis Sci 34:1382.

Mitchell JA, Kohlhaas KL, Matsumoto T, Pollock JS, Forstermann U, Warner TD, Schmidt HHHW, Murad F (1992) Induction of NADPH-dependent diaphorase and nitric oxide synthase activity in aortic smooth muscle and cultured macrophages. Mol Pharmacol 41: 1163-1168.

Mitrofanis J (1989) Development of NADPH-diaphorase cells in the rat's retina. Neurosci Lett 102:165-172. 
Miyachi E-I, Murakami M, Nakaki T (1990) Arginine blocks gap junctions between retinal horizontal cells. Neuroreport 1:107-110.

Moncada S (1992) The l-arginine: nitric oxide pathway. Acta Physiol Scand 145:201-227.

Müller T, Möller T, Berger T, Schnitzer J, Kettenmann H (1992) Calcium entry through kainate receptors and resulting potassium-channel blockade in Bergmann glial cells. Science 256:1563-1566.

Murphy S, Pearce B (1987) Functional receptors for neurotransmitters on astroglial cells. Neuroscience 22:381-394.

Murphy S, Minor RL Jr, Welk G, Harrison DG (1990) Evidence for an astrocyte-derived vasorelaxing factor with properties similar to nitric oxide. J Neurochem 55:349-351.

Murphy S, Simmons ML, Agullo L, Garcia A, Feinstein DL, Galea E, Reis DJ, Minc-Golomb D, Schwartz JP (1993) Synthesis of nitric oxide in CNS glial cells. Trends Neurosci 16:323-328.

Nathan C (1992) Nitric oxide as a secretory product of mammalian cells. FASEB J 6:3051-3064.

Nawy S, Jahr CE (1991) cGMP-gated conductance in retinal bipolar cells is suppressed by the photoreceptor transmitter. Neuron 7:677683.

Newman EA, Frambach DA, Odette LL (1984) Control of extracellular potassium levels by retinal glial cell $\mathrm{K}^{+}$siphoning. Science $225: 1174-$ 1175.

Nowak L, Bregestovski P, Ascher P (1984) Magnesium gates glutamate-activated channels in mouse central neurones. Nature 307:462465.

Palmer RMJ, Moncada S (1989) A novel citrulline-forming enzyme implicated in the formation of nitric oxide by vascular endothelial cells. Biochem Biophys Res Commun 158:348-352.

Palmer RMJ, Ashton DS, Moncada S (1988) Vascular endothelial cells synthesize nitric oxide from L-arginine. Nature 333:664-666.

Pozdnyakov N, Lloyd A, Reddy VN, Sitaramayya A (1993) Nitric oxide-regulated endogenous ADP-ribosylation of rod outer segment proteins. Biochem Biophys Res Commun 192:610-615.

Provis JM, Mitrofanis J (1990) NADPH-diaphorase neurones of human retinae have a uniform topographical distribution. Vis Neurosci 4:619-623.

Sagar SM (1986) NADPH diaphorase histochemistry in the rabbit retina. Brain Res 373:153-158.

Sagar SM (1990) NADPH-diaphorase reactive neurons of the rabbit retina: differential sensitivity to excitotoxins and unusual morphologic features. J Comp Neurol 300:309-319.

Sakai C, Ball A (1994) Invest Ophthalmol Vis Sci 35:1822.

Sandell JH (1985) NADPH diaphorase cells in the mammalian inner retina. J Comp Neurol 238:466-472.

Sarantis M, Mobbs P (1992) The spatial relationship between Müller cell processes and the photoreceptor output synapse. Brain Res 584: 299-304.

Scherer-Singler U, Vincent SR, Kimura H, McGeer EG (1983) Demonstration of a unique population of neurons with NADPH-diaphorase histochemistry. J Neurosci Methods 9:229-234.
Schmidt HHHW, Gagne GD, Nakane M, Pollock JS, Miller MF, Murad $F$ (1992) Mapping of neural nitric oxide synthase in the rat suggests frequent co-localization with NADPH diaphorase but not with soluble guanylyl cyclase, and novel paraneural functions for nitrinergic signal transduction. J Histochem Cytochem 40:1439-1456.

Schmidt K-F, Nöll GN, Yamamoto Y (1992) Sodium nitroprusside alters dark voltage and light responses in isolated retinal rods during whole-cell recording. Vis Neurosci 9:205-209.

Shiells R, Falk G (1992) Retinal on-bipolar cells contain a nitric oxidesensitive guanylate cyclase. Neuroreport 3:845-848.

Simmons ML, Murphy S (1992) Induction of nitric oxide synthase in glial cells. J Neurochem 59:897-905.

Snyder SH (1992) Nitric oxide: first in a new class of neurotransmitters? Science 257:494-496.

Stell WK, Lightfoot DO (1975) Color-specific interconnections of cones and horizontal cells in the retina of the goldfish. J Comp Neurol 159: 473-502.

Straznicky C, Gabriel R (1991) NADPH-diaphorase positive neurons in the retina of Bufo marinus: selective staining of bipolar and amacrine cells. Arch Histochem Cytochem 54:213-220.

Tracey WR, Nakane M, Pollock IS, Forstermann U (1993) Nitric oxide synthases in neuronal cells, macrophages and endothelium are NADPH diaphorases, but represent only a fraction of total cellular NADPH diaphorase activity. Biochem Biophys Res Commun 195: $1035-1040$.

Vallerga S (1981) Physiological and morphological identification of amacrine cells in the retina of the larval tiger salamander. Vision Res 21:1307-1317.

Vaney DI, Young HM (1988) GABA-like immunoreactivity in NADPH-diaphorase amacrine cells of the rabbit retina. Brain Res 474:380-385.

Vaughan DK, Lasater EM (1990) Glial and neuronal markers in bass retinal horizontal and Müller cells. Brain Res 537:131-140.

Venturini CM, Knowles RG, Palmer RMJ, Moncada S (1991) Synthesis of nitric oxide in the bovine retina. Biochem Biophys Res Commun 180:920-925.

Wakakura M, Yamamoto N (1992) Rapid increase of intracellular $\mathrm{Ca}^{2+}$ concentration caused by aminoadipic acid enantiomers in retinal Müller cells and neurons in vitro. Docum Ophthalmol 80:385-395.

Yamamoto R, Bredt DS, Snyder SH, Stone RA (1993) The localization of nitric oxide synthase in the rat eye and related cranial ganglia. Neuroscience 54:189-200.

Yang C-Y, Lukasiewicz P, Maguire G, Werblin FS, Yazulla S (1991) Amacrine cells in the tiger salamander retina: morphology, physiology, and neurotransmitter identification. J Comp Neurol 312:19-32.

Zhang J, Dawson VL, Dawson TD, Snyder SH (1994) Nitric oxide activation of poly(ADP-ribose) synthetase in neurotoxicity. Science 263:687-689. 